\title{
Clinical and genetic aspects of CADASIL syndrome: A systematic review
}

\author{
Mayse Fagundes "; Dalton Matos ${ }^{2}$; Wandklebson da Paz ${ }^{3}$; Andressa \\ Silva $^{4}$; Diogo Brandão ${ }^{5}$; ValériaSotero ${ }^{6}$;osé Alfredo Junior ${ }^{6}$ and \\ Delma de Almeida ${ }^{7}$ \\ ${ }^{1 *}$ Graduation in Biology, Universidade Estadual de Alagoas, \\ Santana do Ipanema, Alagoas, Brazil \\ ${ }^{2}$ Graduate Program in Biotechnology, Universidade Federal de Sergipe, \\ São Cristóvão, Sergipe, Brazil. \\ ${ }^{3}$ Graduate Program in Tropical Medicine, Universidade Federal de Pernambuco, \\ Recife, Pernambuco, Brazil \\ ${ }^{4}$ Graduation in Biology, Universidade Estadual de Alagoas, \\ Santana do Ipanema, Alagoas, Brazil \\ ${ }^{5}$ Graduate Program in Health Sciences, Universidade Federal de Alagoas, Maceió, \\ Alagoas, Brazil \\ ${ }^{6}$ Department of Biologia, Centro Universitário Cesmac, \\ Alagoas, Brazil \\ 7 Department of Biologia, Universidade Estadual de Alagoas, Santana do Ipanema, \\ Alagoas, Brazil. \\ *Corresponding author: Mayse da Silva Fagundes. Departamento de Biologia, Universidade \\ Estadual de Alagoas, Santana do Ipanema, Alagoas, Brazil. CEP: 57500-000. E-mail: \\ maysefagundes@hotmail.com
}

\begin{abstract}
CADASIL is a hereditary cerebrovascular disease, caused by mutations in the NOTCH3 gene that leads to an increased number of cysteines, causing incorrect folding and aggregation in the walls of small cerebral vessels, which result in several clinical characteristics related to the disease. The objective of this study was to identify, through a systematic review, the mutations and polymorphisms involved with the disease and its main clinical characteristics. For this it was necessary to register the review in PROSPERO and then search the data platforms Pubmed, Embase, Scopus, Scielo and
\end{abstract}

Cochrane library with the descriptors "Cognitive Dysfunction" AND "CADASIL"; "Migraine" AND "CADASIL"; "Disorder Moods" AND "CADASIL"; "NOTCH3" AND "CADASIL"; "Stroke" AND "CADASIL". All steps of the review were independently carried out by two researchers. After data extraction the main clinical features related to CADASIL disease were Migraine, TIA/stroke, cognitive impairment, psychiatric disorders, ischemic stroke, migraine with aura, cerebral hemorrhaging, seizures, motor syndrome, and headache. The databases analyzed described 37 mutations, all in the NOTCH3 gene. Thus, through 
the results found, this review showed that CADASIL syndrome can present different clinical features and also its degree of severity depends largely on the type of mutation that occurs in the NOTCH3 gene.

Keywords: CADASIL; NOTCH3; Small Vessel Disease; Migraine.

\section{Introduction}

Cerebral autosomal dominant arteriopathy with subcortical infarcts and leukoencephalopathy (CADASIL) is one of the most common stroke diseases. This syndrome is of genetic etiology and can affect vascular cognitive impairment in adults (Chabriat et al., 2009. Wu et al., 2021). While the concepts of this syndrome are known by all neurologists, there are still some barriers that need to be demystified, requiring further studies on the mechanisms and safest approaches for the development of effective therapy (Chabriat et al., 2020).

Reductions in cortical thickness and white matter volume of the brain have been evident in patients with CADASIL (Pan et al., 2020). Affecting diverse families, this disease functions as a resistance pattern for an autosomal dominant disorder, with about 200 mutations occurring in NOTCH3, in which these mutations often lead to a loss or increase in the number of cysteines and can affect the secondary and tertiary structure of the gene product (Wang, 2018).

When the patient has this mutation, the proteins lose their functionality since the sulfate bridges (responsible for their folding) cannot form, thus causing problems in their final conformation, in addition to generating an accumulation of these proteins in the walls of the small cerebral vessels, which leads to several clinical characteristics related to the disease (Gravesteijn, 2020).

NOTCH3 mutations and the deposition of GOM (Granular Osmophilic Material) in vascular walls is a hallmark of CADASIL. In studies by Ueda et al. (2015), deposits of GOM were found in fresh frozen skin biopsy from patients with NOTCH3 mutations in exons $3,4,6$ and 8. NOTCH3 and GOM deposits were also found in skin blood vessel walls in CADASIL patients with a cysteine-sparing NOTCH3 mutation.

According to Rutten et al. (2019), patients with this disease with EGFr domain 1-6 PV demonstrate the most severe phenotype compared to those with EGFr domain 7-34 PV and EGFr domain 7-34 PV, however, the latter two domains are the most common in populations. For this reason, it is necessary to check all existing mutations reported in the scientific literature.

As the disease progresses, patients begin to present clinical features such as migraine with aura, psychological disorders, recurrent stroke, and dementia. Even with numerous case reports that have been conducted by researchers from other countries, knowledge about CADASIL remains limited due to the various phenotypic manifestations that this disease can present. Thus, we aimed to perform a systematic review of the mutations and polymorphisms involved in CADASIL disease, along with its main clinical features, in order to clarify the molecular mechanism underlying the pathology.

\section{Materials and Methods}

\subsection{Methodological procedures}

This is a systematic review study in which all steps were carried out by two researchers, simultaneously and independently, who initially elected a total of 12,652 studies in the following databases: Pubmed, Embase, Scopus, Scielo and the Cochrane library. All searches were organized in RAAYAN software (https://rayyan.ai/).

The following descriptors were chosen to search the database platforms: "Cognitive Dysfunction" AND "CADASIL"; "Migraine" AND "CADASIL"; "Moods Disorder" AND "CADASIL"; "NOTCH3" AND "CADASIL"; "Stroke" AND "CADASIL". A total of 9,584 duplicate articles were then removed, after which only 3,068 articles remained to pass the inclusion and exclusion criteria.

\subsection{Inclusion and exclusion criteria}

As inclusion criteria, only control group studies were selected, which included the following: individuals who were 18 years or older with a diagnosis of CADASIL (with genetic or phenotypic diagnosis of migraine/headache, with or without aura); patients with a clinical diagnosis of stroke, either ischemic or hemorrhagic; and patients who suffered their first stroke or recurrent stroke, unrelated to the diagnosis of other diseases.

Of the 3,068 articles, 1,115 were excluded, as follows: case reports (136), reviews (570), nonhuman studies (275), editorials (6), letters (27), and clinical trials (101). After applying all the criteria, only 1,953 articles remained, of which 1,851 were excluded because they were not relevant for the analysis, i.e., they did not meet the inclusion criteria for the research. In the end, only 102 articles met the inclusion/exclusion criteria, as shown in Figure 1. 
Figure 1: Flow diagram of the literature review.

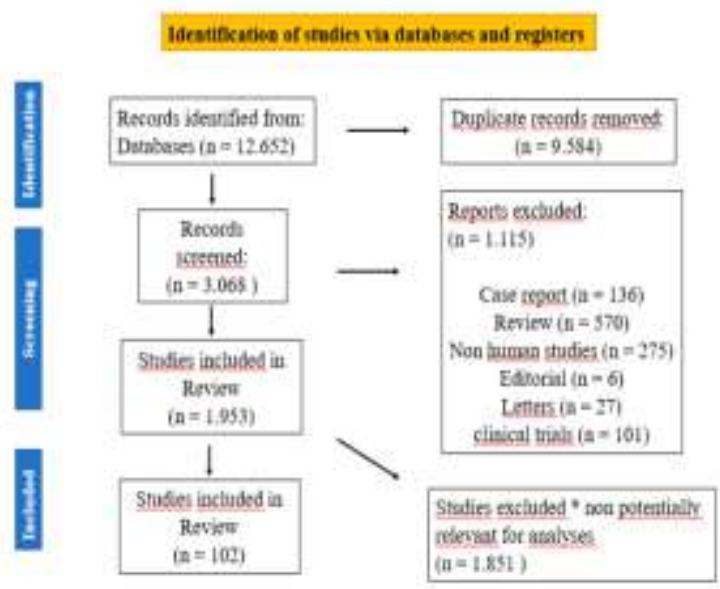

2.3 Quality control

The methodological quality of the studies included was independently assessed by two reviewers according to a set of predefined criteria (Table 1) based on the Thakkinstian et al., (2004) scale, which were modified compared to those used in previously published meta-analytical studies (Cordova et al., 2012; Peng et al., 2013).

The following factors were included in the criteria: case representativeness, mutation representativeness, CADASIL disease case ascertainment, sample size (total number of cases and controls), assessment association, matching case and control participants, and clinical characteristics. Scores ranged from 0 (lowest) to 13 (highest). If the score was 7 or higher, the study was categorized as "high quality"; otherwise, the study was categorized as "low quality." Disagreements were resolved by consensus. Due to the high heterogeneity in study design and outcome measurements among the articles included, a meta-analysis was not performed.

\subsection{Ethical considerations}

This review was registered in the International Prospective Register of Systematic Reviews (PROSPERO, registration number: CRD42020220816) and only started running after the study was approved and released. (Link: https://www.crd.york.ac.uk/prospero/\#myprospero)

\section{Results and Discussion}

In this review, a survey was conducted to investigate the main clinical characteristics of the disease, as well as the most common gene mutations and the new mutations recently discovered. A total of
102 articles were analyzed, of which only 57 $(55.8 \%)$ reported clinical feature related to the disease.

The main clinical features related to CADASIL syndrome were Migraine, TIA/stroke (small stroke-like attack that disappears after minutes or hours), Cognitive impairment, Psychiatric disorders, Ischemic stroke, Migraine with aura, Cerebral hemorrhage, Seizures, Motor syndrome and Headache (Table 1).

According to the clinical characteristics, the frequency of manifestations was observed after the analysis made in several studies related to the disease. Common initial manifestations were stroke or TIA (20.9\%), followed by cognitive dysfunction $(17.8 \%)$, ischemic stroke $(14.7 \%)$, Migraine with aura $(13.9 \%)$ and Migraine without aura $(13.1 \%)$.

Table 1: Clinical characteristics associated with CADASIL syndrome.

\begin{tabular}{|c|c|c|}
\hline Variable & $\begin{array}{c}\text { Absolute } \\
\text { Frequency }\end{array}$ & $\begin{array}{c}\text { Relative } \\
\text { Frequency } \\
\text { (\%) }\end{array}$ \\
\hline Symptoms & 17 & 13.1 \\
\hline Migraine & 27 & 20.9 \\
\hline TIA/ stroke & 23 & 17.8 \\
\hline $\begin{array}{c}\text { Cognitive } \\
\text { impairment }\end{array}$ & 9 & 6.9 \\
\hline $\begin{array}{c}\text { Psychiatric } \\
\text { disturbances }\end{array}$ & 19 & 14.7 \\
\hline Ischemic stroke & 18 & 13.9 \\
\hline $\begin{array}{c}\text { Migraine with } \\
\text { aura }\end{array}$ & 2 & 1.5 \\
\hline $\begin{array}{c}\text { Cerebral } \\
\text { hemorrhage }\end{array}$ & 4 & 3.1 \\
\hline Seizures & 2 & 1.5 \\
\hline $\begin{array}{c}\text { Motor } \\
\text { syndrome }\end{array}$ & 129 & 6.2 \\
\hline Headache & & 100 \\
\hline Total & & \\
\hline
\end{tabular}

Regarding the CADASIL genotype mutations of the patients in the articles analyzed, the databases that were analyzed in this review described 37 mutations, all in the NOTCH3 gene. This gene is responsible for encoding a protein that is considered essential for the maintenance of blood vessels, including those that supply blood to the brain. 
ISSN 2455-6378

The articles report a large number of mutations, and the results of this study show the major mutations related to this gene. The R75P mutation in exon 3 of the NOTCH3 gene was one of the most frequent followed by the mutations: R544C (c.1630C >T) exon 2 and c.268C $>$ T (p.Arg90Cys) exons 3, 4 and 9; R133C exon 4; R587C exon 11 (Table 2).

Table 2. Representative mutations for the CADASIL genotypes found in the studies.

\begin{tabular}{|c|c|c|c|}
\hline Number & Mutation & Exon & Authors \\
\hline 1 & $\begin{array}{l}\text { c. } 268 \mathrm{C}>\mathrm{T} \\
\text { (p.Arg90Cys) }\end{array}$ & $\begin{array}{l}3,4 \\
\& 9\end{array}$ & $\begin{array}{l}\text { He et al., } \\
2016 ; \text { Chen } \\
\text { et al., } 2019\end{array}$ \\
\hline 2 & (p.Arg110>Cys); & 3 & $\begin{array}{l}\text { Bohlega et } \\
\text { al., } 2007\end{array}$ \\
\hline 3 & $\begin{array}{l}\text { R544C } \\
(\mathrm{c} .1630 \mathrm{C}>\mathrm{T})\end{array}$ & 2 & $\begin{array}{l}\text { Choi et al., } \\
\text { 2013; Liao, } \\
\text { et al., 2015; } \\
\text { Lee et al., } \\
\text { 2016; Kim et } \\
\text { al., } 2019\end{array}$ \\
\hline 4 & C49R & 3 & $\begin{array}{l}\text { Wang et al., } \\
2011\end{array}$ \\
\hline 5 & G53C & 3 & $\begin{array}{l}\text { Wang et al., } \\
2011\end{array}$ \\
\hline 6 & C117R & 4 & $\begin{array}{l}\text { Wang et al., } \\
2011\end{array}$ \\
\hline 7 & H170C & 4 & $\begin{array}{l}\text { Wang et al., } \\
2011\end{array}$ \\
\hline 8 & $\mathrm{C} 222 \mathrm{~S}$ & 4 & $\begin{array}{l}\text { Wang et al., } \\
2011\end{array}$ \\
\hline
\end{tabular}

\begin{tabular}{|c|c|c|c|}
\hline 9 & T1098S & 20 & $\begin{array}{l}\text { Wang et al., } \\
2011\end{array}$ \\
\hline 10 & C697T & 4 & $\begin{array}{l}\text { Dong et al., } \\
2003\end{array}$ \\
\hline 11 & $\begin{array}{l}(\mathrm{c} .[244 \mathrm{~T}>\mathrm{C}], \\
\text { p. }[\mathrm{C} 82 \mathrm{R}])\end{array}$ & 3 & $\begin{array}{l}\text { Zea-Sevilla } \\
\text { et al., } 2015\end{array}$ \\
\hline 12 & $\begin{array}{l}\text { Arg141Cys; } \\
\text { Arg207Cys }\end{array}$ & 4 & $\begin{array}{l}\text { Mazzucco et } \\
\text { al., } 2009\end{array}$ \\
\hline 13 & Arg607Cys & 11 & $\begin{array}{l}\text { Mazzucco et } \\
\text { al., } 2009\end{array}$ \\
\hline 14 & $\begin{array}{l}(\mathrm{c} .[244 \mathrm{~T}>\mathrm{C}], \\
\text { p. }[\mathrm{C} 82 \mathrm{R}])\end{array}$ & 3 & $\begin{array}{l}\text { Qureshi et } \\
\text { al., } 2017\end{array}$ \\
\hline 15 & R90C & 3 & $\begin{array}{l}\text { Ungaro et } \\
\text { al., } 2009\end{array}$ \\
\hline 16 & G131C & 4 & $\begin{array}{l}\text { Ungaro et } \\
\text { al., } 2009\end{array}$ \\
\hline 17 & C997G & 18 & $\begin{array}{l}\text { Ungaro et } \\
\text { al., } 2009\end{array}$ \\
\hline 18 & C504R & 10 & $\begin{array}{l}\text { Lee et al., } \\
2009\end{array}$ \\
\hline 19 & $\begin{array}{l}\text { R133C, R141C, } \\
\text { C174F }\end{array}$ & 3 & $\begin{array}{l}\text { Uchino et } \\
\text { al., } 2002\end{array}$ \\
\hline 20 & $\begin{array}{l}\text { (c.307C[T, } \\
\text { p.Arg103*) }\end{array}$ & 3 & $\begin{array}{l}\text { Moccia et } \\
\text { al., } 2015\end{array}$ \\
\hline 21 & R544C & 11 & $\begin{array}{l}\text { Liao et al., } \\
2015\end{array}$ \\
\hline 22 & p.R558C & 11 & Ferreira \\
\hline
\end{tabular}




\begin{tabular}{|c|c|c|c|}
\hline & & & al., 2012 \\
\hline 23 & (p.C1099Y) & 20 & $\begin{array}{l}\text { Ferreira et } \\
\text { al., 2012 }\end{array}$ \\
\hline 24 & C977S & 18 & $\begin{array}{l}\text { Lee et al., } \\
2009\end{array}$ \\
\hline 25 & R141C & 4 & $\begin{array}{l}\text { Lee et al., } \\
2009\end{array}$ \\
\hline 26 & $\mathrm{R} 332 \mathrm{C}$ & 6 & $\begin{array}{l}\text { Lee et al., } \\
2009\end{array}$ \\
\hline 27 & C504R & 10 & $\begin{array}{l}\text { Lee et al., } \\
2009\end{array}$ \\
\hline 28 & S118C & 4 & $\begin{array}{l}\text { Lee et al., } \\
2009\end{array}$ \\
\hline 29 & $\mathrm{R} 133 \mathrm{C}$ & 4 & $\begin{array}{l}\text { Uchino et } \\
\begin{array}{l}\text { al., 2002; } \\
\text { Shindo, et } \\
\text { al., } 2020\end{array}\end{array}$ \\
\hline 30 & R75P & 3 & $\begin{array}{l}\text { Kim et al., } \\
2006 \text {; Wang } \\
\text { et al., 2011; } \\
\text { Choi et al., } \\
\text { 2013; Kim et } \\
\text { al., } 2019\end{array}$ \\
\hline 31 & Y465C & 9 & $\begin{array}{l}\text { Kim et al., } \\
2019\end{array}$ \\
\hline 32 & R1175W VUS & 22 & $\begin{array}{l}\text { Kim et al., } \\
2019\end{array}$ \\
\hline 33 & $\begin{array}{l}\text { (c. }[244 \mathrm{~T}>\mathrm{C}], \\
\text { p. }[\mathrm{C} 82 \mathrm{R}]\end{array}$ & 3 & $\begin{array}{l}\text { Zea-Sevilla } \\
\text { et al., } 2015\end{array}$ \\
\hline
\end{tabular}

\begin{tabular}{|l|l|l|l|}
\hline 34 & R169C & 4 & $\begin{array}{l}\text { Wang et al., } \\
2011\end{array}$ \\
\hline 35 & R587C & 11 & $\begin{array}{l}\text { Kim et al., } \\
\text { 2006; Kim et } \\
\text { al., 2019 }\end{array}$ \\
\hline 36 & c.400TNG & 4 & $\begin{array}{l}\text { Liu et al., } \\
2015\end{array}$ \\
\hline 37 & c.872GNA & 6 & $\begin{array}{l}\text { Liu et al., } \\
2015\end{array}$ \\
\hline
\end{tabular}

Regarding the polymorphisms found, the table below shows the main ones related to CADASIL syndrome. Of the polymorphisms that have been reported in the literature investigated, there is great variety in the European and Asian populations, and some of them showed a higher frequency of reports. Examples are the c. $1725 \mathrm{G} / \mathrm{A}$ and c.1725 polymorphisms found in populations from Italy and China. In Oceanic populations, some polymorphisms related to this syndrome were also described, such as Thr101Thr and rs3815188 in New Zealand and Australia (Table 3).

Table 3. Polymorphisms associated with CADASIL found in the studies.

\begin{tabular}{|l|l|l|l|l|}
\hline $\begin{array}{l}\text { Num } \\
\text { ber }\end{array}$ & Polymorphism & $\begin{array}{l}\text { Exo } \\
\text { ns }\end{array}$ & $\begin{array}{l}\text { Popula } \\
\text { tion }\end{array}$ & $\begin{array}{l}\text { Auth } \\
\text { ors }\end{array}$ \\
\hline 1 & T6746C & 3 & Italy & $\begin{array}{l}\text { Borro } \\
\text { ni et } \\
\text { al., } \\
\text { 2006. }\end{array}$ \\
\hline 2 & C38IT & 3 & London & $\begin{array}{l}\text { Dong } \\
\text { et al., } \\
\text { 2003. }\end{array}$ \\
\hline 3 & G684A & 4 & London & $\begin{array}{l}\text { Dong } \\
\text { et al., } \\
\text { 2003. }\end{array}$ \\
\hline 4 & C738T & 4 & London & $\begin{array}{l}\text { Dong } \\
\text { et al., } \\
\text { 2003. }\end{array}$ \\
\hline 5 & T101T & 3 & $\begin{array}{l}\text { Italy \& } \\
\text { China }\end{array}$ & $\begin{array}{l}\text { Mosc } \\
\text { a et } \\
\text { al., } \\
2011 .\end{array}$ \\
\hline 6 & A202A & 4 & $\begin{array}{l}\text { Italy \& } \\
\text { China }\end{array}$ & $\begin{array}{l}\text { Mosc et } \\
\text { a et } \\
\text { al., }\end{array}$ \\
\hline
\end{tabular}




\begin{tabular}{|c|c|c|c|c|}
\hline & & & & 2011. \\
\hline 7 & Y220Y & 4 & $\begin{array}{l}\text { Italy \& } \\
\text { China }\end{array}$ & $\begin{array}{l}\text { Mosc } \\
\text { a et } \\
\text { al., } \\
2011 .\end{array}$ \\
\hline 8 & $\begin{array}{ll}\text { c. } 2538 & \mathrm{C} / \mathrm{T} ; \\
\text { C846C }\end{array}$ & 16 & $\begin{array}{l}\text { Italy \& } \\
\text { China }\end{array}$ & $\begin{array}{l}\text { Mosc } \\
\text { a et } \\
\text { al., } \\
2011 .\end{array}$ \\
\hline 9 & $\begin{array}{ll}\text { c. } 2742 & \text { A/G; } \\
\text { P914P } & \end{array}$ & 17 & $\begin{array}{l}\text { Italy \& } \\
\text { China }\end{array}$ & $\begin{array}{l}\text { Mosc } \\
\text { a et } \\
\text { al., } \\
2011 .\end{array}$ \\
\hline 10 & $\begin{array}{ll}\text { c.1140 } & \text { T/C; } \\
\text { P380P } & \end{array}$ & 7 & $\begin{array}{l}\text { Italy \& } \\
\text { China }\end{array}$ & $\begin{array}{l}\text { Mosc } \\
\text { a et } \\
\text { al., } \\
2011 .\end{array}$ \\
\hline 11 & $\begin{array}{ll}\text { c.1487 } & \mathrm{C} / \mathrm{T} ; \\
\mathrm{P} 496 \mathrm{~L} & \end{array}$ & 9 & $\begin{array}{l}\text { Italy \& } \\
\text { China }\end{array}$ & $\begin{array}{l}\text { Mosc } \\
\text { a et } \\
\text { al., } \\
2011 \text {. }\end{array}$ \\
\hline 12 & $\begin{array}{l}\text { c. } 1725 \text { G/A and } \\
\text { c. } 1725 \mathrm{G} / \mathrm{C}\end{array}$ & 11 & $\begin{array}{l}\text { Italy \& } \\
\text { China }\end{array}$ & $\begin{array}{l}\text { Mosc } \\
\text { a et } \\
\text { al., } \\
2011 .\end{array}$ \\
\hline 13 & His170Ar & 3 & $\begin{array}{l}\text { Australi } \\
\text { a \& \& } \\
\text { New } \\
\text { Zealand }\end{array}$ & $\begin{array}{l}\text { Roy } \\
\text { et al., } \\
2012 \text {. }\end{array}$ \\
\hline 14 & $\begin{array}{l}\text { Thr101Thr, } \\
\text { rs3815188 }\end{array}$ & 3 & $\begin{array}{l}\text { Australi } \\
\text { a \& \& } \\
\text { New } \\
\text { Zealand }\end{array}$ & $\begin{array}{l}\text { Roy } \\
\text { et al., } \\
2012 .\end{array}$ \\
\hline 15 & $\begin{array}{l}\text { NM } \\
000435.2: c .679+ \\
60 G>A\end{array}$ & 4 & $\begin{array}{l}\text { Australi } \\
\text { a \& \& } \\
\text { New } \\
\text { Zealand }\end{array}$ & $\begin{array}{l}\text { Roy } \\
\text { et al., } \\
2012 \text {. }\end{array}$ \\
\hline
\end{tabular}

In the scientific literature, there are few studies focused on systematic review which investigate the mutations and polymorphisms related to CADASIL syndrome. Although studies have shown that migraine is one of the most frequent symptoms (Bohlega et al., 2007), new studies suggest that ischemic stroke has a higher frequency compared to migraine (Chuah et al., 2001; Wang et al., 2011; Ueda et al., 2015), corroborating what was observed in this review. Other authors have also observed a prevalence of recurrent ischemic events as one of the main risk factors for the development of the syndrome (He et al., 2016).
In a study of 90 patients in 44 hospitals, the prevalence rate of migraine in Japanese patients possessing CADASIL was observed to be lower than in European populations, and this clinical feature was related to vascular risk factors. These included hypertension, dyslipidemia, and diabetes mellitus. In addition, 33 patients $(37.5 \%)$ had one or more of these vascular risk factors (stroke), 59 patients $(67.0 \%)$ had stroke-like episodes while 31 patients $(35.2 \%)$ had dementia (Shindo et al., 2020).

In the work by He et al., (2016), it was shown for the first time that recurrent ischemic events, family history and temporal lobe involvement in MRI can be used to differentiate between the types of CADASIL. Another way of differentiation was reported in a study by Dziewulska et al. (2008), where brain and skin biopsies of CADASIL-affected patients were analyzed and an increased expression of ubiquitin was found in the blood vessel walls.

Regarding CADASIL syndrome, in the vast majority of cases there is a pattern of autosomal inheritance with stroke or dementia occurring in relatives at a young age. According to the work of Chabriat et al. (2009), the researchers suggest that genetic testing is indicated if the patient has clinical features of the syndrome in combination with neuroimaging features or a positive family history, especially if there are no cases of hypertension. The need is more debatable if a patient with no family history of the syndrome has migraine with aura and some hypersignals on T2-weighted images.

The mutations related to the CADASIL genotype concerning the NOTCH3 gene bring a great heterogeneity of small changes related to both clinical and genetic aspects. The NOTCH3 gene, the most frequently described gene in this systematic review, encodes a transmembrane receptor protein similar to the epidermal growth factor receptor. More than 200 mutations in the NOTCH3 gene have been discovered in patients with the disease. Most often these mutations are nonsynonymous substitutions, and very rarely, mutations are small insertions, deletions, or changes in the mutation site (Wang, 2018). 
In CADASIL Syndrome, mutations occurring in the NOTCH3 gene and its effect on the NOTCH3 receptor appear to trigger a cascade of imbalances with profound effects on multiple levels, because the extracellular accumulation of NOTCH3 can interfere in the normal physiological functions of other molecules. In their work Ferrante et al., (2019) showed that the disruption of blood vessels in CADASIL also involves several molecular systems at the endothelial, smooth muscle and neural cell levels related to the maintenance of cellular health, the delivery of important nutrients and also vasoreactivity.

The R544C mutation (c.1630C> T) has been described more than once in the literature, being reported by four different papers. This mutation may be associated with an older age of onset of disease development and a lower percentage of moderate to severe cerebral white matter lesions in the anterior temporal lobe (Liao et al., 2015; Lee et al., 2016).

In studies conducted by Matsushima et al. (2016), among the main clinical characteristics related to CADASIL syndrome the highest rate was of stroke episodes, cognitive decline, depression and episodes of headaches. Similar results were also found by He et al. (2021), who reported that over the course of the disease, ischemic stroke/transient ischemic attack (TIA) was the most common symptom, as well as other clinical manifestations such as cognitive impairment, hemorrhagic stroke, migraine, and psychiatric disorders.

In the studies by He et al. (2016) and Chen et al. (2019), the c.268C > T (p.Arg90Cys) mutation appears to be the most likely genetic cause of disease development and is one of the most common mutations in NOTCH3. Mutation frequencies, however, differ among populations and range from 0.4/1000 in African Americans to 11.7/1000 in South Asians. Some mutations are present in many different populations; the p.Arg578Cys mutation and thep.Arg1231Cys mutation, for example, are found every $1 / 4$ to every six populations (Rutten et al., 2016).

This mutation leads to a substitution of the amino acid cystine for an arginine at position 90 of the amino acid sequence in EGFr 2. Mutations in NOTCH3 can cause CADASIL syndrome with a wide range of phenotypes despite the type of mutation and also if GOM (granular osmiophilic material) deposits are observed. (Chen et al., 2019).
In the study by Servilla et al. (2015), the researchers described a patient with all the clinical features associated with CADASIL disease that is associated with a previously undescribed missense mutation (c. [244T> C], p. [C82R]) in NOTCH3. This new mutation adds to the list of pathogenic mutations already known to be responsible for CADASIL, which are associated with an odd number of cysteine residues in any of the epidermal growth factor-like repeats of the NOTCH3 receptor protein.

Another interesting aspect was that most of the mutations were located in exons 3 and 4 . In their study, Moccia et al., (2015) revealed in DNA analyses the c.307C> T mutation in the NOTCH3 gene. According to the authors, this variant is located in the epidermal growth factor (EGF)-like region of exon 3 and causes the substitution of arginine for a stop codon at position 103 of the protein (p.Arg103X).

Thus, the formation of such a premature stop codon would result in the production of a truncated protein lacking the amino acids encoded by exon 3 and subsequent exons (4/33) and therefore characterized by the absence of all EGF-like repeat domains except EGF-like 1. Interestingly, in contrast to the distribution pattern of exon 2 to 6 mutations in Caucasians, mutations in Chinese are predominantly located in exons 11, 18, and 4 (Lee et al., 2009). In addition to CADASIL-related mutations, a survey of polymorphisms found in the studies was conducted.

The type of polymorphism seems to play an important role in the development of the disease. In a work done by Abramycheva et al. (2015), it was demonstrated that most patients had relatively rapid progression, while 4 patients remained stable for 6 to 20 years. They found a marked polymorphism of clinical findings in carriers of an identical mutation in the R182C polymorphism, the age at onset of symptoms differed by 21 years (from 31 to 52 years), while in R207C carriers these had acute onset with recurrent strokes or a chronic progressive course. 
Matsushima et al., (2016) also showed that this polymorphism is a very rare variant in the European population (allele frequency, 1.268e-05, $8.321 \mathrm{e} 06$ and 8.321e-06, respectively), but not in Asians. In studies that have investigated the association between the NOTCH3 polymorphism and migraine, it was found that this polymorphism was not associated with migraine or migraine subtypes. Of the polymorphisms that have already been reported in the literature, T6746C appears to be the most common, resulting in a Val/Ala amino acid substitution at residue 2223, which is located in the intracellular domain of the cell (Borroni et al., 2006).

According to the work by Dong (2003), three polymorphisms were identified, among which two had already been reported (C381T; G684A) and a new and rare one was described for the first time (C738T), but none of them encoded amino acid changes nor were they associated with any clinical features. Therefore, it is very likely that these variants are not functional. The researchers further highlighted a study conducted in Caucasians of European descent living in Australia, showing a significant association of the $\mathrm{C} 381 \mathrm{~T}$ variant.

In a systematic study, Wei et al., (2019) showed that in none of the genetic models were the NOTCH3 rs1043994 and rs3815188 polymorphisms significantly associated with lacunar stroke. Furthermore, the NOTCH3 rs3815188 polymorphism was not significantly associated with atherothrombotic stroke in any genetic model. CADASIL is the most common cause of hereditary stroke and cognitive vascular impairment in adults.

Some of the limitations present in the study were the potential heterogeneity of the studies that were selected, the possible biases of individual studies and even publication bias, and not least the continuing need for updating. Another difficulty encountered in this study was the paucity of scientific papers focusing on polymorphisms in CADASIL disease.

\section{Conclusions}

This review shows that CADASIL syndrome may present different clinical features and also its degree of severity very much depends on the type of mutation that occurs in the NOTCH3 gene. The fact that different mutations in the NOTCH3 gene may have different effects on NOTCH3 signaling makes it difficult to correlate a hypothesis where there is a single pathogenicity mechanism in CADASIL. Despite CADASIL being a relatively frequent disease in several populations around the world, there have not been many studies related to the disease in Brazil. This leaves room for more studies about this syndrome, so that people who have this disease and have no knowledge about it can have access to more information and, above all, seek alternatives to reduce or even adopt palliative measures in relation to the progression of this disease.

\section{Acknowledgments}

\section{Competing Interest}

The authors declare that they have no conflicts of interest.

Prospero protocol: protocol prospero.pdf

\section{Funding}

This research did not receive any specific grant from funding agencies in the public, commercial, or notfor-profit sectors.

\section{Abbreviations \\ CADASIL, cerebral autosomal dominant arteriopathy with subcortical infarcts and leukoencephalopathy.}

EGF, epidermal growth factor.

GOM, granular osmiophilic material.

TIA, transient ischemic attack.

\section{References}

[1] Abramycheva N, Stepanova M, Kalashnikova L, Zakharova M, Maximova M, Tanashyan M, et al. (2015) New mutations in the NOTCH3 gene in patients with cerebral autosomal dominant arteriopathy with subcortical infarcts and leucoencephalopathy (CADASIL). Journal of the neurological sciences, v. 349, n. 1-2, p. 196-201 Available https://doi.org/10.1016/j.jns.2015.01.018.

[2] Bohlega S, Shubili AA, Edris A, Alreshaid A, Alkhairallah T, AlSous M W, et al. (2007) Saeed et al. CADASIL in Arabs: clinical and genetic findings. BMC medical genetics, v. 8, n. 1, p. 1-5 Available at: doi:10.1186/1471-2350-8-67.

[3] Borroni B, Brambilla C, Liberini P, Rao R, Archetti S, Venturelli E, et al. (2006) Investigating the association between NOTCH3 polymorphism and migraine. Headache: The Journal of Head and Face Pain, v. 46, n. 2, p. 317-321 Available 
https://doi.org/10.1111/j.1526-

4610.2006.00344.x.

[4] Chuah TL, Tan KM, Flanagan S, Hyland V, Sullivan AA, Henderson R, et al. (2001) CADASIL (Cerebral autosomal dominant arteriopathy with subcortical infarcts and leucoencephalopathy): An Australian perspective. Journal of clinical neuroscience, v. 8, n. 5, p. 404-406 Available at: https://doi.org/10.1054/jocn.2000.0848.

[5] Chabriat H, Joutel A, Dichgans M, TournierLasserve E, Bousser M-G (2009) CADASIL. The Lancet Neurology 8, n. 7, p. 643-653 Available at: doi:10.1016/s1474-4422(09)701279.

[6] Córdoba M, Consalvo D, Moron DG, Kochen S, Kauffman MA (2012) SLC6A4 gene variants and temporal lobe epilepsy susceptibility: a meta-analysis. Molecular biology reports, v. 39, n. 12, p. 10615-10619 Available at: https://doi.org/10.1007/s11033-012-1949-5.

[7] Choi JC, Song S-K, Lee JS, Kang S-Y, Kang J-H (2013) Diversity of stroke presentation in CADASIL: study from patients harboring the predominant NOTCH3 mutation R544C. Journal of Stroke and Cerebrovascular Diseases, v. 22, n. 2 p. 126-131 Available at: https://doi.org/10.1016/j.jstrokecerebrovasdis.20 11.07.002.

[8] Choi JC, Lee K-H, Song S-K, Lee JS, Kang S-Y, Kang J-H (2013) Screening for NOTCH3 gene mutations among 151 consecutive Korean patients with acute ischemic stroke. Journal of Stroke and Cerebrovascular Diseases, v. 22, n. 5, p. 608-614 Available at: https://doi.org/10.1016/j.jstrokecerebrovasdis.20 11.10.013.

[9] Chen X, Deng S, Xu H, Hou D, Hu P, Yang Y, et al. (2019) Novel and Recurring NOTCH3 Mutations in Two Chinese Patients with CADASIL. Neurodegenerative Diseases, v. 19, n. 1, p. 35-42 Available at: https://doi.org/10.1159/000500166.

[10] Chabriat H, Joutel A, Tournier-Lasserve E, Bousser MG (2020) CADASIL: yesterday, today, tomorrow. European journal of neurology, v. 27, n. 8 , p. $1588-1595$ Available at: https://doi.org/10.1111/ene.14293.

[11] Dziewulska D, Rafalowska J (2008) Is the increased expression of ubiquitin in CADASIL syndrome a manifestation of aberrant endocytosis in the vascular smooth muscle cells? Journal of clinical neuroscience, v. 15, n. 5, p. $535-540$ Available https://doi.org/10.1016/j.jocn.2007.06.022.
[12]Dong Y, Hassan A, Zhang Z, Huber D, Dalageorgou C, Markus HS (2003) Yield of screening for CADASIL mutations in lacunar stroke and leukoaraiosis. Stroke, v. 34, n. 1, p. 203-206 Available at: https://doi.org/10.1161/01.STR.0000048162.168 52.88 .

[13] Ferrante EA, Cudrici CD, Boehm M (2019) CADASIL: new advances in basic science and clinical perspectives. Current opinion in hematology, v. 26, n. 3, p. 193 Available at: doi: 10.1097/MOH.0000000000000497.

[14] Gravesteijn G, Dauwerse JG, Overzier M, Brouwer G, Hegeman I, Mulder AA, et al. (2020) Naturally occurring NOTCH3 éxon skipping attenuates $\mathrm{NOTCH} 3$ protein aggregation and disease severity in CADASIL patients. Human molecular genetics, v. 29, n. 11, p. 1853-1863 Available at: doi: 10.1093/hmg/ddz285.

[15] He D, Chen D, Li X, Hu Z, Yu Z, Wang W, et al. (2016) The comparisons of phenotype and genotype between CADASIL and CADASILlike patients and population-specific evaluation of CADASIL scale in China. The journal of headache and pain, v. 17, n. 1, p. 1-9 Available at: doi: 10.1186/s10194-016-0646-5.

[16] Hu Y, Sun Q, Zhou Y, Yi F, Tang H, Yao L, et al. (2021) NOTCH3 Variants and GenotypePhenotype Features in Chinese CADASIL Patients. Frontiers in genetics, v. 12 Available at: https://doi.org/10.3389/fgene.2021.705284.

[17] Kim Y, Kim JS, Kim G, No YJ, Yoo HW (2006) Two novel mutations of the NOTCH3 gene in Korean patients with CADASIL. Mutation Research/Fundamental and Molecular Mechanisms of Mutagenesis, v. 593, n. 1-2, p. 116-120 Available at: https://doi.org/10.1016/j.mrfmmm.2005.06.031.

[18] Kim Y, Choi EJ, Choi CG, Kim G, Choi JH, Yoo $\mathrm{H}$, et al. (2006) Characteristics of CADASIL in Korea: a novel cysteine-sparing NOTCH3 mutation. Neurology, v. 66, n. 10, p. 1511-1516 Available at: https://doi.org/10.1212/01.wnl.0000216259.9981 1.50 .

[19] Kim Y, Lee S-H (2019) Novel characteristics of race-specific genetic functions in Korean CADASIL. Medicina, v. 55, n. 9, p. 521.

[20] Available https://doi.org/10.3390/medicina55090521.

[21] Lee Y-C, Liu C-S, Chang M-H, Lin K-P, Fuh J-L, $\mathrm{Lu}$ Y-C, et al. (2009) Population-specific spectrum of NOTCH3 mutations, MRI features and founder effect of CADASIL in Chinese. 
Journal of neurology, v. 256, n. 2, p. 249-255 Available at: https://doi.org/10.1007/s00415-0090091-3.

[22] Lee JS, Ko K, Oh J-H, Park JH, Lee HK, 2016. Phenotypic features of cerebral autosomaldominant arteriopathy with subcortical infarcts and leukoencephalopathy subjects with R544C mutation. Dementia and neurocognitive disorders, v. 15, n. 1, p. 15-19 Available at: https://doi.org/10.12779/dnd.2016.15.1.15.

[23] Liao YC, Hsiao CT, Fuh JL, Chern CM, Lee WJ, Guo YC, et al. (2015) Characterization of CADASIL among the Han Chinese in Taiwan: distinct genotypic and phenotypic profiles. PloS one, v. 10, n. 8, p. e0136501

[24] Available https://doi.org/10.1371/journal.pone.0136501.

[25] Liu X, Zuo Y, Sun W, Zhang W, Lv H, Huang Y, et al. (2015) The genetic spectrum and the evaluation of CADASIL screening scale in Chinese patients with NOTCH3 mutations. Journal of the neurological sciences, v. 354, n. 12, p. 63-69 Available at: https://doi.org/10.1016/j.jns.2015.04.047.

[26] Matsushima T, Conedera S, Tanaka R, Li Y, Yoshino H, Funayama M, et al. (2017) Genotype-phenotype correlations of cysteine replacement in CADASIL. Neurobiology of aging, v. 50, p. 169. e7-169. e14.

[27] Available at: https://doi.org/10.1016/j.neurobiolaging.2016.10. 026 .

[28] Mazzucco S, Anzola GP, Ferrarini M, Taioli F, Olivato S, Burlina AP, et al. (2009) Cerebral autosomal dominant arteriopathy with subcortical infarcts and leucoencephalopathy and right-to-left shunt: lack of evidence for an association in a prevalence study. European neurology, v. 61, n. 1, p. 46-49. Available at: https://doi.org/10.1159/000165350.

[29] Moccia M, Mosca L, Erro R, Cervasio M, Allocca R, Vitale C, et al. (2015) Hypomorphic $\mathrm{NOTCH} 3$ mutation in an Italian family with CADASIL features. Neurobiology of aging, v. 36, n. 1, p. 547. e5-547. e11.Available at: https://doi.org/10.1016/j.neurobiolaging.2014.08. 021 .

[30] Mosca L, Marazzi R, Ciccone A, Santilli I, Bersano A, Sansone V, et al. (2011) NOTCH3 gene mutations in subjects clinically suspected of CADASIL. Journal of the neurological sciences, v. 307, n. $1-2$, p. 144-148. Available at: doi: 10.1016/j.jns.2011.04.019.

[31] Pan H, Huang Q, Ban S, Du X, Su J, Liu J (2020) Brain structural changes in CADASIL patients: A morphometric magnetic resonance imaging study. Neuroscience Letters, v. 738, p. 135388. Available https://doi.org/10.1016/j.neulet.2020.135388.

[32] Peng Q, Mo C, Qin A, Lao X, Chen Z, Sui J, et al. (2013) MDM2 SNP309 polymorphism contributes to endometrial cancer susceptibility: evidence from a meta-analysis. Journal of Experimental \& Clinical Cancer Research, v. 32, n. 1 , p. 1-9 Available at: https://doi.org/10.1186/1756-9966-32-85.

[33] Qureshi AI, Khan MT, Naveed O, Saleem MA, (2017) Potential New Cysteine Sparing Mutation in the NOTCH3 Gene in a Patient with Nonfamilial CADASIL-like Disease. Journal of vascular and interventional neurology, v. 9, n. 6 , p. 51. Available at: https://www.ncbi.nlm.nih.gov/pmc/articles/PMC 5805898/.

[34] Roy B, Maksemous N, Smith RA, Menon S, Davies G, Griffiths LR (2012) Two novel mutations and a previously unreported intronic polymorphism in the NOTCH3 gene. Mutation Research/Fundamental and Molecular Mechanisms of Mutagenesis, v. 732, n. 1-2, p. 3$8 \quad$ Available at: https://doi.org/10.1016/j.mrfmmm.2012.02.004.

[35] Rutten JW, Dauwerse HG, Gravesteijn G, Belzen, MJV., Grond, JV, Polke, JM, et al. (2016) Archetypal NOTCH3 mutations frequent in public exome: implications for CADASIL. Annals of clinical and translational neurology, v. 3 , n. 11 , p. 844-853 Available at: https://doi.org/10.1002/acn3.344.

[36] Rutten JW, Eijsden BJV, Duering M, Jouvent E, Opherk C, Pantoni L, et al. (2019) The effect of NOTCH3 pathogenic variant position on CADASIL disease severity: NOTCH3 EGFr 1-6 pathogenic variant are associated with a more severe phenotype and lower survival compared with EGFr 7-34 pathogenic variant. Genetics in Medicine, v. 21, n. 3, p. 676-682 Available at: https://doi.org/10.1038/s41436-018-0088-3.

[37] Shindo A, Tabei K-I, Taniguchi A, Nozaki H, Onodera O, Ueda A, et al. (2020) A Nationwide Survey and Multicenter Registry-Based Database of Cerebral Autosomal Dominant Arteriopathy With Subcortical Infarcts and Leukoencephalopathy in Japan. Frontiers in Aging Neuroscience, v. 12, p. 216.Available at: https://doi.org/10.3389/fnagi.2020.00216.

[38] Uchino M, Hirano T, Uyama E, Hashimoto Y (2002) Cerebral autosomal dominant arteriopathy with subcortical infarcts and leukoencephalopathy (CADASIL) and CADASIL-like disorders in Japan. Annals of the 
New York Academy of Sciences, v. 977, n. 1, p. 273-278 Available

at:

https://doi.org/10.1111/j.1749

6632.2002.tb04826.x

[39] Ungaro C, Mazzei R, Conforti FL, Sprovieri T, Servillo P, Liguori M, et al. (2009) CADASIL: extended polymorphisms and mutational analysis oft the NOTCH3 gene. Journal of neuroscience research, v. 87 , n. 5, p. 1162-1167. Available at: https://doi.org/10.1002/jnr.21935.

[40] Ueda A, Ueda M, Nagatoshi A, Hirano T, Ito T, Arai N, et al. (2015) Genotypic and phenotypic spectrum of CADASIL in Japan: the experience at a referral center in Kumamoto University from 1997 to 2014. Journal of neurology, v. 262, n. 8, p. 1828-1836. Available at: https://doi.org/10.1007/s00415-015-7782-8.

[41] Wang Z, Yuan Y, Zhang W, Lv H, Hong D, Chen B, et al. (2011) NOTCH3 mutations and clinical features in 33 mainland Chinese families with CADASIL. Journal of Neurology, Neurosurgery \& Psychiatry, v. 82, n. 5, p. 534-539 Available at: http://dx.doi.org/10.1136/jnnp.2010.209247.
[42]Wang MM (2018) CADASIL. Handbook of clinical neurology, v. 148, p. 733-743 Available at: https://doi.org/10.1016/B978-0-444-640765.00047-8

[43] Wei KL, Griffiths LR, Looi I, Kooi CW (2019) Association of NOTCH3 gene polymorphisms with ischemic stroke and its subtypes: A metaanalysis. Medicina, v. 55, n. 7, p. 351 Available at: https://doi.org/10.3390/medicina55070351.

[44] Wu X, Zhang A, Li Y, Lei X, Guo SP, Tian T, et al. (2021) A Chinese CADASIL family with $p$. R578C mutation at éxon 11 of the NOTCH3 gene. Clinical Neurology and Neurosurgery, v. 208, p. 106833. Available at: https://doi.org/10.1016/j.clineuro.2021.106833.

[45]Zea-Sevilla MA, Bermejo-Velasco P, SerranoHeranz R, Calero M (2015) Cerebral autosomal dominant arteriopathy with subcortical infarcts and leukoencephalopathy (CADASIL) associated with a novel $\mathrm{C} 82 \mathrm{R}$ mutation in the NOTCH3 gene. Journal of Alzheimer's Disease, v. 43 , n. 2, p. 363-367 Available at: doi: 10.3233/JAD-141218. 